\title{
What Drives Home Bias? \\ Evidence from Fund Managers' Views
}

\author{
Torben Lütje, University of Hannover, Germany \\ Lukas Menkhoff, University of Hannover, Germany
}

Discussion paper No. 296

May 2004

ISSN 0949-9962

\begin{abstract}
A survey of fund managers reveals home bias for these sophisticated investors in an unrestricted setting. Proximity, perceived informational advantage and higher expected returns are confirmed as accompanying factors. In addition, the home bias of equity managers is also related to institutional, informational and behavioral characteristics. The perceived informational advantage does not seem to be valid. Multivariate analyses indicate that home bias is mainly related to relative return optimism, non-fundamental information and peculiar behavior towards risk. We interpret these as characteristics of less than fully rational behavior. It is consistently found that this pattern does not apply to bond managers.
\end{abstract}

JEL-Classification: F 30, G 15, G 23

Keywords: Home bias, institutional investors, local information advantage, non-fundamental information, disposition effect

We would like to thank seminar participants and in particular Thomas Gehrig for helpful comments. We also thank the German Investment Association BVI for its very useful supporting letter. Financial support by the Wissenschaftsförderung der Sparkassenorganisation e.V., the research promotion arm of the German savings bank organization, is gratefully acknowledged.

Corresponding author: Lukas Menkhoff, Department of Economics, University of Hannover, Königsworther Platz 1, D-30167 Hannover, Germany, menkhoff@gif.unihannover.de 


\section{What Drives Home Bias? \\ Evidence from Fund Managers' Views}

\section{Introduction}

Professionals invest larger shares in home assets than would be warranted based on capital market theory. They thus give away available opportunities to increase their risk-adjusted returns. This (equity) home bias puzzle has attracted plentiful investigation, yet a fully convincing explanation so far remains to be found (Lewis, 1999, Karolyi and Stulz, 2002). Several approaches can claim theoretical or empirical substantiation, but they do not necessarily exclude each other. The questions that are therefore raised are: which factors are decisive, and are we confident that all important factors have been considered? This paper contributes to the literature by answering both questions. We conclude that more factors than have generally been discussed could "explain" home bias in a univariate setting. Some of these also hold in a multivariate approach. They clearly point towards driving forces of home bias that are associated with less than fully rational behavior (see Shiller, 2003).

Early explanations of home bias focused on institutional barriers to international investment. This, however, does not seem to be relevant any longer in a financially integrated world (see also Tesar and Werner, 1995, Warnock, 2002, Ahearne et al., 2002). Additionally, uncertainty about the advantages of international diversification does not really provide a barrier (Lewis, 1999). Another line of argument has advanced informational asymmetries between countries, so that home preference reflects an informational advantage of local investors (see e.g. Coval and Moskowitz, 2001, in a domestic setting). As the basic alternative explanation, French and Poterba (1991) have suggested behavioral approaches, of which the "relative optimism" of local investors towards home assets seems to be empirically well established even among fund managers (Shiller et al., 1996, Strong and Xu, 2003).

The focus on the most sophisticated group of fund managers is important if the issue of rationality is at stake. Home bias means sub-optimal diversification and it is known from earlier literature that private investors tend to hold poorly diversified portfolios (Lease et al., 1974, Baxter and Jermann, 1997, Odean, 1998). By contrast, 
professional fund managers are nowadays well informed about financial market theory and regularly apply instruments of portfolio optimization. They understand the advantages of diversification in general, and of international diversification in particular. Moreover, they command over institutional requirements to implement international investment strategies. Finally, studies indicate that they may be less prone to behavioral distortions in their decision-making than private investors (Shapira and Venezia, 2001). These arguments raise the question of whether home bias is a preference of (some) fund managers as well.

It can be misleading to interpret the decisions of fund managers based on the ex post outcome, as their portfolios are often influenced by less professional capital owners. The latter may for example restrict international investments so that effective asset allocation is different from what professionals prefer. To circumvent this restriction and learn about undistorted fund managers' views, they have been asked via a survey questionnaire. The core question addresses their preferred international asset allocation independent from any fund restrictions.

In general, a survey approach can provide evidence that is complementary to more conventional empirical methods. Its relative advantage is its broad scope and identification of groups in the market as well as of motivational clusters. ${ }^{1}$ These advantages are important here, as the paper focuses on an enlarged set of driving forces for home bias. Moreover, the simplifying notion of "home bias" is analyzed for disaggregated data so that persons may show home bias of various degrees. The distinction into degrees of home bias, in the extremes as showing any home bias at all versus none, allows the examination of driving forces in more detail than previously.

The responses of 234 fund managers in Germany revealed that they would invest about three times as much capital in the home market than would be advisable from the viewpoint of international diversification. Although this degree of home bias is much less than can be observed from private investors, it is still remarkably high considering that the fund managers made these decisions about their international allocation without any restriction. Moreover, further findings in the literature can be confirmed with our different type of data. Home bias is related to proximity, perceived informational advantage and expected higher returns. What is new is the finding that

\footnotetext{
${ }^{1}$ Prominent work includes Shiller (1989), Shafir, Diamond and Tversky (1997), Blinder (2000) and Howitt's (2002) survey on labor market research.
} 
all of these relations occur simultaneously. This makes it difficult to discriminate between different hypotheses.

An extension of these relations into the areas of institutional, informational and behavioral characteristics shows that further factors - not discussed in earlier studies - are related to home bias as well. Home bias is an attribute that is related to lower fund volumes, to a more intensive reliance on non-fundamental analysis and to some behavioral distortions of decision-making. Multivariate analyses indicate that home bias is related to items of the earlier literature as well as to the newly analyzed characteristics. Reflecting on the exogeneity of variables, the driving forces appear to be characteristic of less than fully rational behavior.

The paper is structured into five more sections. Section 2 describes data. Section 3 analyzes literature hypotheses with our different type of (survey) data, whereas in Section 4 new hypotheses are tested. Multivariate regressions are presented in Section 5 and, finally, Section 6 concludes.

\section{Data}

This questionnaire survey study accounts for the responses of 234 fund managers in Germany. Between April and June 2003, all mutual and pension fund management companies that manage securities portfolios were addressed (but not those managing real estate). We received a supporting letter from the respective German investment association "BVI", which encouraged member companies to participate. 51 out of 66 companies responded, yielding a rate of $77.3 \%$. Due to numerous and repeated contact attempts with each company and the partial use of email-copies, we cannot give a response rate for persons asked to participate. However, absolute participation and the response rate of fund management companies can be compared with earlier surveys of a similar kind, indicating a favorable response. ${ }^{2}$

Many interviews with fund managers from various investment companies and in several cities were conducted in advance in order to ensure that questions as well as

\footnotetext{
${ }^{2}$ For US foreign exchange dealers Cheung and Chinn (2001) realize 108 responses and a personal response rate of about $8 \%$. Arnswald (2001) has 275 individual responses and a participation of 60 German equity management companies (by way of the authority of the Deutsche Bundesbank). Gehrig and Menkhoff (2002) report a response from 29 fund management companies, representing $51 \%$, for the more narrow field of foreign exchange management.
} 
response categories were clearly understandable and relevant. A test run of the questionnaire was performed as well.

A bottleneck for survey studies is the limited time of professionals and their comparatively low incentive to answer questions in a careful manner. As an indication of the usefulness of our data, we thus show the current position of respondents within their companies in Table 1. It is obvious that the hierarchy in these firms is reflected in responses. It is of particular significance that the answers were not primarily given by less experienced and less influential junior asset managers. Moreover, the data on age, experience and working hours that is also shown in Table 1, indicates in an exemplary manner that the data seems to be consistent in its structure.

\section{Survey findings on literature hypotheses}

\subsection{The existence of home bias}

The determination of a home bias is usually based on the ex post analysis of (international) securities holdings. One possible way is to analyze foreign equity held by domestic residents. Another way, for example, analyzes the share of foreign securities in the portfolios of institutional investors (Lewis, 1999). These procedures involve an identification problem, as it is not entirely clear who is really responsible for the observed home bias. In particular, it seems plausible to assume that less informed private investors are more prone to a home bias than professional investors (see Grinblatt and Keloharju, 2001). The influence of private investors may stretch into the domain of institutional investors, as the former either puts restrictions on asset management or invests more heavily in domestically oriented funds. In any case, earlier research has hardly identified an undistorted home bias among professional asset managers.

This survey study thus adds to available evidence by asking fund managers directly and under the condition that their fund restrictions don't influence their preferred international asset allocation. The response from German fund managers is very clear in its qualitative direction: the vast majority would invest a larger share of the hypothetical investment in Germany than would be suggested by Germany's share in world markets alone. Figure 1 shows the distribution of the preferred share of investments in Germany: 29\% allocate up to $5 \%$ of the investment for the German market. As respondents mostly answer at full 5-percentage numbers, there is hardly any response in between $5 \%$ and $10 \%$. This implies that $71 \%$ prefer a weight for the 
German market of approximately $10 \%$ and more. This contrasts with the market capitalization of Germany, which was about $3 \%$ for stock markets and $7.5 \%$ for bond markets, respectively, during the first half of $2003 .{ }^{3}$ Due to this difference, it seems plausible that bond managers allocate even as much as $15.5 \%$ for the German market and thus more than the $11.8 \%$ of equity managers. In sum, $71 \%$ of the responding German fund managers would overweigh Germany in their preferred portfolio. Germany is over-represented in these portfolios by a factor of about three. ${ }^{4}$ This indicates a very clear home bias for professional fund managers - even without any restrictions from their customers. ${ }^{5}$

In another analysis, the hypothesis of a "home bias at home" can be tested. Coval and Moskowitz (1999) find that for the US market local proximity enforces home bias. Applying this idea to the European context, one might expect that the European region is preferred to other regions in the world by those who show a home bias. This effect - which can also be recognized for the UK in French and Poterba (1991, Table 2) and for Canadian investments from the US (Tesar and Werner, 1995) - shows up in the survey data as well. Although the home bias for Germany implies a higher share for this market and thus enforces overall lower shares for the remaining markets, the preference for Germany goes hand in hand with a preference for Europe. The detailed regional investment allocation can be inferred from Figure 2. In addition, a rank correlation of regional investment shares confirms the finding, as the positive and statistically significant correlation between German and European investments is contrasted by the negative correlation between Germany and the US or Asia respectively.

In summary, home bias very clearly exists with regard to coverage $(71 \%)$, amount (12-16\% allocation vs. $3-8 \%$ world market share) and structure (home bias at home), even among professional asset managers.

\footnotetext{
${ }^{3}$ The German stock market share is taken from Morgan Stanley's MSCI All Countries-index. The bond market share is calculated by referring to the Bank for International Settlements' (2003, Tables 12A, 16A) statistics on domestic and international debt securities markets.

${ }^{4}$ The overrepresentation of Germany ranges between a factor of two for the response from bond managers compared to the German share in world bond markets and a factor of four for the response from equity managers compared to the German share in world equity markets.

${ }^{5}$ According to Lewis (1999, Table 2), institutional investors from Germany are more internationally oriented than from many other countries as their percentage holdings of foreign securities are higher.
} 


\subsection{Suggested relations of home bias}

There have been two major contributions towards an explanation of the home bias puzzle that have found substantial empirical support. The first approach being advanced to explain home bias is the hypothesis of "informational advantage". Gehrig (1993) shows that the existence of systematically better-informed local investors would lead to a capital market equilibrium with overweighing of home assets. Kang and Stulz (1997) find that for the case of Japan, foreign investors indeed prefer those stocks about which they have better information due to a better international presence of firms (see also Ahearne et al., 2002). Coval and Moskowitz (1999) demonstrate that for the US, investors prefer stocks with local proximity (see also Huberman, 2001). So far, the literature is compatible with the view that investors prefer assets about which they feel to be better informed. Unclear, however, is whether they are really better informed. In a follow-up paper, Coval and Moskowitz (2001) find that home bias in their US sample is indeed accompanied by higher returns, indicating that local information can be valuable.

The second hypothesis, that of "relative optimism", was advanced by Shiller et al. (1996). It claims that local investors regard the fundamental situation in their home country as being relatively better than investors from abroad would. This does not imply that local investors give their home country an absolute advantage - even a relative advantage justifies a portfolio allocation that overweighs the home market. What Shiller et al. measured in the US and Japan for the first time has been extended by Strong and Xu (2003) to a broader sample. Thus, "relative optimism" can now be regarded as a stylized fact helping to understand home bias.

Our survey allows the testing of this latter hypothesis in a new way. Due to the focus on individual data, the issue is not one of optimism relative to foreign investors, but one of the relative optimism of those fund managers revealing home bias. In addition, the data allows us to distinguish the responses of equity and bond managers.

With the survey data available here, it can be tested whether these two hypotheses on home bias receive support. Regarding the hypothesis of "informational advantage", it has been asked whether fund managers see a local advantage at work (see Table 2.A). The answers fully support the hypothesis. The stronger the home bias, the more fund managers believe in an informational advantage. This relation is even closer for the group of equity managers only, whereas the coefficient for bond managers is much smaller and insignificant. It seems obvious that fund managers, in 
particular equity managers, believe in their own advantage, which encourages the exploitation of this advantage by heavily investing in the home market. Concerning possible implications, the expected one-month ahead $90 \%$ intervals for two stock market indices were questioned. If investors with home bias truly had better information, one might expect that they are able to better predict future prices. However, the relation between a correct EuroStoxx 50 forecast (coming closest to a local market, as the European market is also overweighed) and German investment is statistically insignificant for equity and bond managers (see Annex 1 ). ${ }^{6}$ So our data does not reveal a clear informational advantage.

Regarding "relative optimism", the ten-year stock return expectations for the major markets in the world were inquired about. Table 2.B shows that the preference for home assets is positively related to a relatively better expectation for the German market. This relative optimism is statistically highly significant in comparison with the rest of Europe and the USA. Regarding subgroups within the market, the finding is particularly strong for equity managers, but does not hold for bond managers. The response of bond managers does not change either if we relate their degree of home bias to the expected bond market return (shown in Table 2.B).

In summary, our survey data of fund managers complements earlier approaches. It confirms the findings of perceived informational advantages and relative optimism for equity managers, although not for bond managers. What may be surprising, moreover, is the fact that both effects co-exist simultaneously. This raises the question of which effect may be stronger and whether even other unexplored factors may be important in understanding the home bias phenomenon.

\section{Survey findings on further relations}

The broad coverage of the survey provides the opportunity to test further relations that go beyond earlier literature. We group these new items into three categories: the first one is mainly institution oriented, whereas the two others resemble the above tested hypotheses of "informational advantage" and "relative optimism", i.e. they are information and behavior oriented.

\footnotetext{
${ }^{6}$ Whereas this analysis refers to forecast accuracy, i.e. the first moment, Section 4.3 addresses the expected width of future prices, i.e. the second moment, with similar results.
} 


\subsection{Relations of home bias with institutional characteristics}

Starting with institutional characteristics that might accompany home bias, there is no theory needed for an exploratory approach, but the working hypothesis is rather straight forward: viewing home bias from the perspective of functioning markets, the fact of a clear home preference would be related with signs of (possible) inferiority in several dimensions. In this sense, home bias may be practiced by fund managers that are younger and less experienced, work less, reach lower positions, have less education, receive lower bonus payments or other incentives and are given fewer asset volumes to manage.

Relating the degree of German investment share (taken as our measure of home bias) with these items provides a clear result: fund managers showing home bias are most often quite "normal" with regard to their institutional characteristics. In particular, they are neither less experienced nor less successful regarding their positional level. There is one highly significant difference, however: home biased equity managers account for a lower volume (see Table 3.A). Nevertheless, this is the only consistently significant finding, whereas other indications of inferiority are of more fragile nature. So, working hours and education level tend to be less for equity managers showing home bias, a finding which is sometimes significant depending on sample size (see Table 3.B and C). In summary, home bias is not significantly related with institutional characteristics in general. The group of equity managers, however, shows some tendency towards indicators of inferiority, whereas there is no such relation for bond managers.

\subsection{Relations of home bias with informational characteristics}

The hypothesis of "informational advantage", discussed in Section 3.2, assumes that local investors would have a valuable information advantage. German fund managers who prefer investments in Germany tend to agree with this view more than others. So, what characterizes their behavior towards information? The above assessed relations with institutional characteristics have already shown that home bias is not related to either higher or lower effort in information gathering. Moreover, company size, proxying the degree of private information due to enhanced research facilities, tends to be smaller for home biased equity fund managers, though this relation is not robust. Thus, home bias does not seem to be related to the amount and general quality of information. In a next step, the type of information is analyzed. 
In the survey question on this subject, fund managers were asked to assess the importance of six different sources of information for their decision making. If home bias were based on better information on local markets these respondents should use fundamental information at least as intensively as the average market participant. The finding reveal, however, that this is clearly not the case. Table 4.A shows the responses concerning preferred sources of information for equity managers; bond managers do not show any significant relations. Home bias is positively related to the higher relevance of all kinds of information, but with one exception - fundamental facts. Moreover, home bias is even positively associated with alternative sources of information. There is a statistically significant relation with chart analysis/technical indicators and with statements of economic opinion leaders. These are sources of information that have been classified as non-fundamental, for example by Shleifer and Summers (1990).

In order to check the robustness of this finding, Table 4.B gives the responses to the phrase "to follow the herd". This phrase seems to describe the application of mostly trend-following technical analysis. Indeed, it is given much credence by equity managers with a German preference, although not at all by bond managers. Thus, the response pattern on information sources is consistent with the responses regarding trend following behavior. It reveals that the informational acquaintance of home bias is not a particular interest in fundamental analysis that might cause an informational advantage, but rather in non-fundamental analysis. This poses a severe problem for the hypothesis of informational advantage: charts and statements of prominent opinion leaders rely on information that is common knowledge and thus not new. Moreover, this type of information does not possess an obvious local advantage.

The direct evidence gained here for fund managers is thus compatible with Huberman's (2001, p.676) inference about household investments that "the [home] bias favoring the familiar does not reflect the exploitation of informational advantage". There emerges thus the possibility that a particular behavioral pattern might be responsible for home bias.

\subsection{Relations of home bias with behavioral characteristics}

Home bias can be seen as a strategy to accept risk from insufficient diversification. The most obvious behavioral characteristic that might accompany home bias would hence be a higher tolerance towards risk taking in investment decisions. The 
responses show, however, that fund managers preferring German assets are not significantly different from others: they neither accept greater risks in a general lottery environment nor classify themselves as less risk-averse in their investment decisions, although home biased equity managers tend to regard themselves as somewhat less risk-averse (not presented here).

So, if home bias does not seem to be related to any particular risk attitude in general, it could still be related with a misperception of risks in foreign markets. Huberman (2001) and Kilka and Weber (2000) argue in this respect (following Heath and Tversky, 1991) that perceived competence in local stocks might lead to an underestimation of local risks and an overestimation of foreign risks. In this respect, fund managers were asked to give their estimate of the 90 per cent interval of future stock price indices. If home bias were related to wider expected intervals for foreign markets, this might explain why this particular group of fund managers hesitates to invest abroad. The finding presented in Table $5 . A$ is rather surprising, however, as the home bias of equity managers correlates with a significantly smaller estimation of the future price interval in the US stock index Dow Jones. This significantly narrow expected interval is also found for the most popular European stock index EuroStoxx 50 , but to a lesser extent. So, the home bias of equity managers is related to a generally low expectation of risk, which may be interpreted as overconfidence (Klayman et al., 1999, Oberlechner and Osler, 2003), whereas there is no significant relation for bond managers (the insignificant coefficients are not presented in Table 5). More important, however, is that home bias is hardly motivated by particularly high expected risk abroad. So, we turn to further aspects of risk consideration.

One of the most prominent concepts in this respect is the disposition effect. Inspired by Kahneman and Tversky's (1979) highlighting of loss aversion, Shefrin and Statman (1985) point out the "disposition to sell winners too early and to ride losers too long", in short, the disposition effect. This effect has been proven in many ways, among others by Grinblatt, Titman and Wermers (1995) for mutual fund managers who buy winning stocks but fail to systematically sell losers to the same degree. Odean (1998) shows that private investors lose money by sticking to losing stocks. The lesson from earlier studies is that the disposition effect is a source of relative losses. It is therefore relevant for home bias that the disposition effect is significantly stronger for those equity managers who prefer German investments, although not for 
bond managers (Table 5.B). What might be the motivation behind this finding, and how can it be related to earlier findings?

Shefrin and Statman (1985) discuss a variety of concepts, such as loss aversion and regret avoidance. A positive relation of disposition effect and loss aversion holds for the equity managers in this survey too (not presented), but loss aversion is not significantly related to home bias in a robust way. So, what might cause the disposition effect of this group if it goes beyond general loss aversion? Respondents were requested to respond to a certain scenario in a tournament structure - namely, they were to assume that their own fund was under-performing in relation to the relevant benchmark near the end of the period. Even though the literature is controversial on the theoretically expected reaction to underperformance, there are strong reasons to expect no change in strategy due to a strictly fundamental approach. In fact, however, the home bias of equity managers was found to correspond with a decrease in the relative risk level (Table 5.C). So, there is a preference not to fall short by too much.

It seems intuitive that this latter motivation could be a root cause "to go with the trend" and to rely on "technical analysis". The revealed kind of risk aversion also does not seem to demonstrate strong self-confidence. This might fit to the observed responsibility for lower volumes (Section 4.1).

To summarize Section 4: there appears to be further sources of home bias for equity managers than those identified in the previous literature. This raises the question: which ones are really important?

\section{The relative importance of home bias' driving forces}

\subsection{Statistical analyses of driving forces}

So far, fund managers' views have revealed five different groups of driving forces that may be responsible for home bias. According to the above presented findings, the preference for home bias is, first, related to a belief in an informational advantage and, second, relative return optimism towards home assets. For equity managers, three further sources of home bias have been analyzed in Section 4, i.e. institutional, informational and behavioral motivations. In order to analyze relative importance, it seems useful to reduce the multitude of characteristics mentioned so far. We perform this task for equity managers by following two approaches: first, a stepwise 
elimination of insignificant determinants in a linear regression is applied, and second, a principal component analysis is run.

Regarding the stepwise regression, the 21 variables covered in the tables above are reduced until there remains a regression with six independent variables that are each significant. The adjusted R-square of this approach is about 0.25 and thus not too bad, taking the high deviations in survey data into account. Moreover, the remaining variables fit quite well into the discussion of Sections 3 and 4 . In particular, all five groups of variables that have been mentioned are covered by the six variables. Details given for model 1 in Table 6 show that better local information, comparatively better expected German performance, lower fund volumes, reliance on information from economic opinion leaders and estimation of a (too) narrow Dow Jones interval are the most useful variables in this approach. Further restricting the number of variables in models 2 and 3 indicates that local information advantage is less important than other variables.

As another means to reduce information from the universe of 21 variables, principal component analyses are applied. We calibrate them conventionally, first by excluding factors with an eigenvalue of below one and excluding variables that have a loading of less than 0.5 on any component. This procedure yields three components that are quite clearly driven by a few variables each: component one mainly reflects the expected higher returns from investments in Germany in comparison with Europe and the USA. Component two is characterized by information sources. The third component is basically driven by education alone, an institutional characteristic. Exact figures are given in Annex 2. If we restrict another principal component analysis to a maximum of three components, it is again found that the three components can be traced back first to behavioral characteristics, second to informational characteristics and third to "relative optimism" in returns (see Annex 3 for details).

In summary, the home bias of equity managers appears to be driven by more forces than often previously assumed. In particular, three forces stand out in a quite robust fashion: relative optimism in returns, as identified in earlier studies, but also informational and behavioral factors all play a useful role in improving our understanding of home bias. 


\subsection{A qualitative discussion of driving forces}

Despite this finding of a broad set of driving forces, one may speculate about a hierarchy of determinants of home bias which cannot be identified by the multivariate methods applied above. Instead, one can argue about the exogeneity and possible causality of the variables - an exercise that ends up strengthening the behavioral argument. Starting with the informational advantage, there is evidence that the advantage perceived does not hold in reality, as proponents neither invest in fundamental analysis nor perform better in forecasting. Similarly, the better performance of the home market has previously been revealed as wishful thinking. It may therefore be cautiously inferred that the variables "informational advantage" and "relative return optimism" are themselves influenced by psychological forces (see also Shiller et al., 1996, Huberman, 2001, Strong and Xu, 2003).

Coming to the next group of determinants, institutional characteristics, the lower volume of assets under management being related to home bias is probably a consequence and not a cause. Causality may be attributed to less working hours and lower educational level, although these findings are not robustly significant. So, turning to the next group, what about informational characteristics? Having already argued that findings do not support the notion of home bias being the result of heavy investment into information production, the kind of information preferred seems to be of non-fundamental character. Reflecting on the nature of non-fundamental information, it could also be influenced by the same behavioral forces as home bias, rather than causing the latter. Hence, if there is a truly causal relationship between the identified driving forces and home bias, behavioral aspects will most probably be important, either indirectly as discussed above or directly.

Due to the complexity of driving forces, any judgment on the type of fund managers that prefer home bias must be speculative. It seems plausible, however, that two ingredients are necessary: the core ingredient is a strong and peculiar kind of risk aversion, generating the disposition effect, tournament behavior and motivating towards trend-related information preferences which are of non-fundamental character. Because of their peculiar form of risk aversion, these fund managers may falsely believe that home assets are less risky. This finding is more specific than the general aspect of "familiarity" (Huberman, 2001, see Grinblatt and Keloharju, 2001) The second ingredient, wishful thinking, has more stabilizing character, as it helps to rationalize home bias via perceived informational advantages and expected higher returns 
(see also Strong and Xu, 2003). Moreover, the institutional characteristics tend in the same direction, in the sense that home bias is tentatively related to inferiority.

Even though these analyses contribute to a consistent picture, the picture holds for equity managers only and thus still leaves a puzzle behind: bond managers allocate a higher share in the home market than equity managers, but their preference is by and large not significantly related to any views or characteristics. This might indicate that international diversification is not a major issue for bond managers and thus mainly left to idiosyncratic influences. Interview evidence indeed reveals an understanding of risk that is not focused on the expected earnings of firms and national markets but is based on the bond ratings and duration of the portfolio held. These ratings are much more homogeneous than earning forecasts, so insecurity is lower and thus the resulting need to diversify. Duration as the second focus of attention is unrelated to international diversification. Nevertheless, this puzzle seems to be worthy of deeper consideration.

\section{Conclusions}

This paper examines the home bias puzzle from a different angle than most other literature. The data used is the result of a questionnaire survey performed in 2003 whereby 234 German equity and bond managers responded. This basis allows for results that are new in several respects: first, the survey directly asks for the preferred international allocation of fund managers and thus circumvents the identification problem when inferences are drawn from asset holdings. Second, the focus is exclusively on the sophisticated fund managers, so that any findings could not be justified by limited knowledge or marginal market importance. Third, the puzzle is analyzed separately for equity and bond managers.

We find that fund managers reveal home bias even in a setting without investment restrictions. Their beliefs motivate a preference for local assets, which is in agreement with hypotheses in previous literature. Equity managers trust in an informational advantage and expect higher returns. Informational advantage, however, often appears to be little more than a perceived advantage, as fund managers with a home preference do not forecast stock indices better and rely less than others on fundamental analysis. Moreover, "higher expected returns" have been unmasked in an earlier multi-period study as permanent "relative optimism". 
In a more extensive exploration of home bias' driving forces that have so far been discussed, the survey approach allows to the further analysis of relations of interest. Their common theme is to examine characteristics of inferiority, information used and attitudes of risk aversion. It was indeed found that equity managers have a tendency towards indicators of inferiority, that they rely on non-fundamental sources of information and that they reveal tentative underestimation of true risks as well as strong aspects of risk aversion.

It may be plausible to identify two roots of this behavior, i.e. strong risk aversion and wishful thinking: home biased equity managers are tentatively afraid to realize relative losses as indicated by the disposition effect and their very risk-averse tournament behavior. They consequently seem to rely more than others on analytical instruments that make them behave in accordance with the herd, which again insures against negative deviation from the benchmark. Their reliance on home assets could fit into this picture, as it may reveal a false perception of risk reduction. Wishful thinking, mentioned by Strong and Xu (2003) in their discussion of relative optimism, could also help to explain the perceived informational advantage.

In summary, the survey approach is used to reach beyond earlier insights. Evidence suggests that the underlying theme of previous hypotheses, as well as of new hypotheses examined here, is one of less than fully rational behavior. When categorizing responding fund managers, this applies to equity managers only but not to bond managers. 


\section{References}

Ahearne, Alan G., William L. Griever and Francis E. Warnock (2002), Information Costs and Home Bias: An Analysis of U.S. Holdings of Foreign Equities, Journal of International Economics, forthcoming; Board of Governers of the Federal Reserve System International Finance Discussion Papers 691, updated.

Arnswald, Torsten (2001), Investment Behaviour of German Equity Fund Managers, An Exploratory Analysis of Survey Data, Deutsche Bundesbank Discussion Paper 08/01, Frankfurt.

Bank for International Settlements (2003), BIS Quarterly Review, September 2003, Basel.

Baxter, Marianne and Urban J. Jermann (1997), The International Diversification Puzzle Is Worse than You Think, American Economic Review, 87:1, 170180.

Blinder, Alan S. (2000), Central-Bank Credibility: Why Do We Care? How Do We Build It?, American Economic Review, 90, 1421-1431.

Cheung, Yeung-W. and Menzie D. Chinn (2001), Currency Traders and Exchange Rate Dynamics: A Survey of the US Market, Journal of International Money and Finance, 20, 439-471.

Coval, Joshua D. and Tobias J. Moskowitz (1999), Home Bias at Home: Local Equity Preference in Domestic Portfolios, Journal of Finance, 54, 2045-2073.

Coval, Joshua D. and Tobias J. Moskowitz (2001), The Geography of Investment: Informed Asset Trading and Asset Prices, Journal of Political Economy, 109:4, 811-841.

French, Kenneth R. and James M. Poterba (1991), Investor Diversification and International Equity Markets, American Economic Review, 81:2, 222-226.

Gehrig, Thomas P. (1993), An Information Based Explanation of the Domestic Bias in International Equity Investment, Scandinavian Journal of Economics, 95:1, 97-109.

Gehrig, Thomas and Lukas Menkhoff (2002), The Use of Flow Analysis in Foreign Exchange: Exploratory Evidence, Journal of International Money and Finance, forthcoming; CEPR Discussion Paper 3221. 
Grinblatt, Mark and Matti Keloharju (2001), How Distance, Language, and Culture Influence Stockholdings and Trade, Journal of Finance, 56:3, 1053-1073.

Grinblatt, Mark, Sheridan Titman and Russ Wermers (1995), Momentum Investment Strategies, Portfolio Performance, and Herding: A Study of Mutual Fund Behavior, American Economic Review, 85:5, 1088-1105.

Heath, Chip and Amos Tversky (1991), Preference and Belief: Ambiguity and Competence in Choice under Uncertainty, Journal of Risk and Uncertainty, 4:1, 5-28.

Howitt, Peter (2002), Looking Inside the Labor Market: A Review Article, Journal of Economic Literature, 40:1, 125-138.

Huberman, Gur (2001), Familiarity Breeds Investment, Review of Financial Studies, $14: 3,659-680$.

Kahnemann, Daniel and Amos Tversky (1979), Prospect Theory: An Analysis of Decision under Risk, Econometrica, 47, 263-291.

Kang, Jun-Koo and René M. Stulz (1997), Why Is there a Home Bias? An Analysis of Foreign Portfolio Equity Ownership in Japan, Journal of Financial Economics, 46:1, 3-28.

Karolyi, G. Andrew and René M. Stulz (2002), Are Financial Assets Priced Locally or Globally?, NBER Working Paper 8994.

Kilka, Michael and Martin Weber (2000), Home Bias in International Stock Return Expectations, Journal of Psychology and Financial Markets, 1, 176-192.

Klayman, Joshua, Jack B. Soll, Claudia González-Vallejo and Sema Barlas (1999), Overconfidence: It Depends on How, What and Whom You Ask, Organizational Behavior and Human Decision Processes, 79:3, 216-247.

Lease, Ronald C., Wilbur G. Lewellen und Gary G. Schlarbaum (1974), The Individual Investor: Attributes and Attitudes, Journal of Finance, 29:2, 413-433.

Lewis, Karen K. (1999), Trying to Explain Home Bias in Equities and Consumption, Journal of Economic Literature, 37, 571-608.

Oberlechner, Thomas and Carol L. Osler (2003), Overconfidence in Currency Markets, Working Paper, Brandeis University.

Odean, Terrance (1998), Are Investors Reluctant to Realize Their Losses?, Journal of Finance, 53, 1775-1798.

Shafir, Eldar, Peter Diamond and Amos Tversky (1997), Money Illusion, Quarterly Journal of Economics, 112:2, 341-374. 
Shapira, Zur and Itzhak Venezia (2001), Patterns of Behavior of Professionally Managed and Independent Investors, Journal of Banking and Finance, 25, 1573-1587.

Shefrin, Hersh and Meir Statman (1985), The Disposition to Sell Winners Too Early and Ride Losers Too Long: Theory and Evidence, Journal of Finance, 40:3, 777-790.

Shiller, Robert J. (1989), Market Volatility, Cambridge MA: MIT Press.

Shiller, Robert J. (2003), From Efficient Markets Theory to Behavioral Finance, Journal of Economic Perspectives, 17:1, 83-104.

Shiller, Robert J., F. Kon-Ya and Y. Tsutsui (1996), Why Did the Nikkei Crash? Expanding the Scope of Expectations Data Collection, Review of Economics and Statistics, 78, 156-164.

Shleifer, Andrei and Lawrence H. Summers (1990), The Noise Trader Approach to Finance, Journal of Economic Perspectives, 4:2, 19-33.

Strong, Norman and Xinzhong Xu (2003), Understanding the Equity Home Bias: Evidence from Survey Data, Review of Economics and Statistics, 85:2, 307312.

Tesar, Linda L. and Ingrid M. Werner (1995), Home Bias and High Turnover, Journal of International Money and Finance, 14, 467-492.

Warnock, Francis E. (2002), Home Bias and High Turnover Reconsidered, Journal of International Money and Finance, 21, 795-802. 
TABLE 1. Respondents' current position within own company

\begin{tabular}{lrccc}
\hline & Responses & Age $^{1)}$ & Experience $^{1)}$ & $\begin{array}{c}\text { Working } \\
\text { hours }^{1}\end{array}$ \\
CIO / CEO & $104.4 \%$ & $\sim 41$ years & $\sim 13$ years & $\sim 51$ hours \\
Head of AM team & $3816.6 \%$ & $\sim 36$ years & $\sim 8$ years & $\sim 49$ hours \\
Senior asset manager & $10947.6 \%$ & $\sim 35$ years & $\sim 7$ years & $\sim 46$ hours \\
Junior asset manager & $7231.4 \%$ & $<31$ years & $<4$ years & $\sim 46$ hours \\
Total & 229 & $\sim 33$ years & $\sim 6$ years & $\sim 47$ hours \\
\hline
\end{tabular}

This table is based on 224-229 responses, depending on the answers to each question.

1) Approximate figures arise from the calculation of the mean answers given to the respective response categories that comprehend ranges of age, experience or working hours.

\section{FIGURE 1. Home bias of German fund managers}

Request: "Please allocate the investment of $€ 10$ mill. in a way to the following regions that the shares add up to $100 \%$ (leave for this task the restrictions of your funds unconsidered): _ Germany, __ Europe (without Germany), _ USA and Canada, __ Asia, _ Emerging Markets."

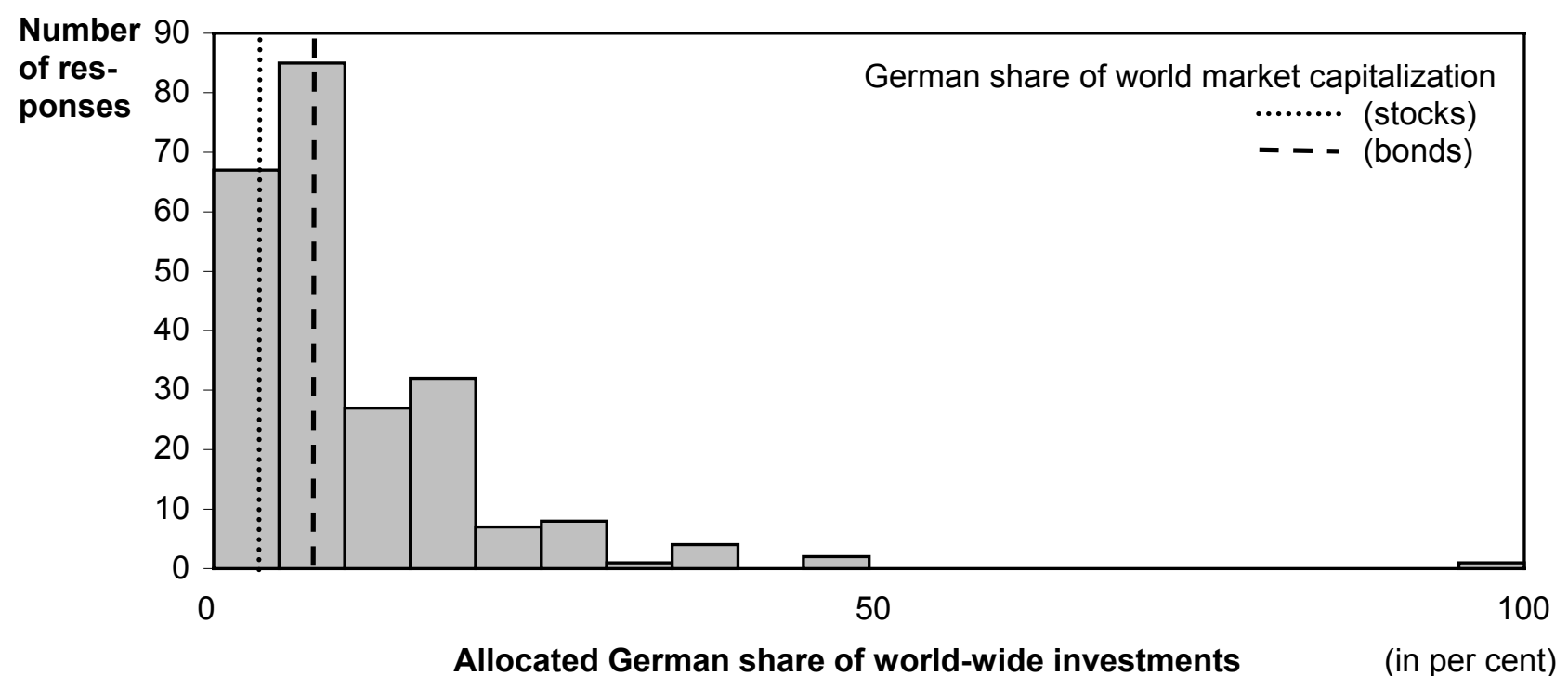

This figure is based on 234 responses. The intervals are given for a width of five percentage points. The German shares of world market capitalization of $3 \%$ for stocks and $7.5 \%$ for bonds are taken from Morgan Stanley's MSCl and the Bank for International Settlement (2003) respectively. 
FIGURE 2. Preferred international asset allocation depending on the allocated German share

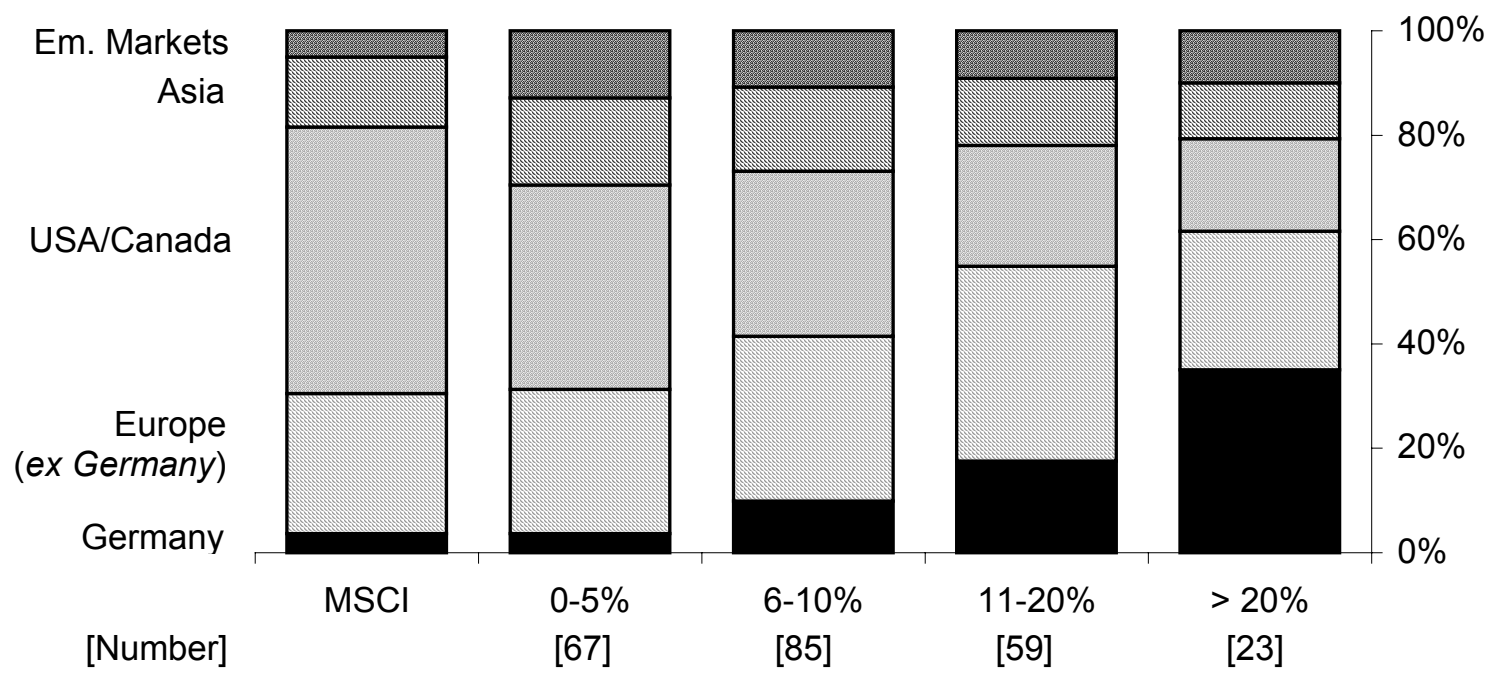

Allocated German share of world-wide investments

Data underlying this figure are described in Figure 1.

TABLE 2. Findings on the hypotheses of information advantage and relative optimism

\begin{tabular}{|c|c|c|c|c|}
\hline A. & \multicolumn{4}{|c|}{$\begin{array}{l}\text { Statement: "As a domestic asset manager I benefit from better information on domestic securi- } \\
\text { ties compared to market players abroad." Six response categories from } 1 \text { (complete disagree- } \\
\text { ment) to } 6 \text { (complete agreement). }\end{array}$} \\
\hline \multirow[t]{3}{*}{ B. } & \multicolumn{4}{|c|}{$\begin{array}{l}\text { "Which long-term market expectations do you have for the next } 10 \text { years?" Equity managers/ } \\
\text { bond managers: "Average stock/bond market yield p.a. in local currency: _ Germany, __ } \\
\text { Europe,__ USA, _ Asia." }\end{array}$} \\
\hline & & \multicolumn{3}{|c|}{$\begin{array}{c}\text { Spearman rank correlation coefficients with German in- } \\
\text { vestment share ( } p \text {-value in parentheses) }\end{array}$} \\
\hline & & All managers & Equity managers & Bond managers \\
\hline A. & $\begin{array}{l}\text { Domestic managers } \\
\text { better informed }\end{array}$ & $0.171^{* * *}(0.009)$ & $0.226^{* * *}(0.006)$ & $0.063(0.670)$ \\
\hline B. & $\begin{array}{l}\text { Yield GER - EU } \\
\text { Yield GER - USA } \\
\text { Yield GER - Asia }\end{array}$ & $\begin{array}{l}0.210^{* * *}(0.003) \\
0.195^{* * *}(0.005) \\
0.082 \quad(0.260)\end{array}$ & $\begin{array}{ll}0.211^{* *} & (0.014) \\
0.243^{* * *}(0.004) \\
0.128 & (0.145)\end{array}$ & $\begin{array}{l}0.032(0.853) \\
-0.080(0.650) \\
-0.085(0.668)\end{array}$ \\
\hline
\end{tabular}

Stars refer to level of significance: ${ }^{\star} 10 \%,{ }^{* *} 5 \%,{ }^{* * *} 1 \%$. 
TABLE 3. Findings on the relation of home bias with institutional characteristics

\begin{tabular}{|c|c|c|c|c|}
\hline $\bar{A}$. & \multicolumn{4}{|c|}{$\begin{array}{l}\text { "Your personal responsibility for assets under management (in } € \text { mill.):" six categories from } \\
\text { "<50" up to ">10,000". }\end{array}$} \\
\hline B. & \multicolumn{4}{|c|}{ "Average working hours per week:" six categories from "<41" up to ">60". } \\
\hline C. & \multicolumn{4}{|c|}{ "Educational level: __ non-academic degree, __ academic degree". } \\
\hline & \multicolumn{4}{|c|}{$\begin{array}{l}\text { Spearman rank correlation coefficients with German investment share } \\
\text { (p-value in parentheses, number of respondents in brackets) }\end{array}$} \\
\hline & $\begin{array}{l}\text { Investment } \\
\text { segment }\end{array}$ & full sample & & are $>0, \leq 50$ \\
\hline A. & $\begin{array}{l}\text { Stocks } \\
\text { Bonds }\end{array}$ & $\begin{array}{lll}-0.225^{* * *} & (0.008) & {[n=137]} \\
0.049 & (0.747) & {[n=45]}\end{array}$ & $\begin{array}{l}-0.233^{* *} \\
-0.115\end{array}$ & $\begin{array}{l}(0.008)[n=129] \\
(0.478)[n=40]\end{array}$ \\
\hline B. & $\begin{array}{l}\text { Stocks } \\
\text { Bonds }\end{array}$ & $\begin{array}{l}(0.124)[n=147] \\
(0.182)[n=48]\end{array}$ & $\begin{array}{c}-0.145^{*} \\
0.133\end{array}$ & $\begin{array}{l}(0.089)[n=138] \\
(0.395)[n=43]\end{array}$ \\
\hline C. & $\begin{array}{l}\text { Stocks } \\
\text { Bonds }\end{array}$ & $\begin{array}{l}(0.111)[n=147] \\
(0.131)[n=45]\end{array}$ & $\begin{array}{l}-0.146^{*} \\
-0.035\end{array}$ & $\begin{array}{l}(0.088)[n=138] \\
(0.827)[n=41]\end{array}$ \\
\hline
\end{tabular}

There are no robust relations of home bias with: gender, marital status, age, professional experience, average period of data procurement and research, current position within company, average bonus received, mutual fund or special fund (such as pension fund) and four different criteria of performancebased remuneration. Stars refer to level of significance: ${ }^{*} 10 \%,{ }^{* *} 5 \%$, ${ }^{* *} 1 \%$.

TABLE 4. Findings on the relation of home bias with informational characteristics for equity managers

A. $\quad$ "Please assess the following sources of information used in making investment decision." Six
response categories from 1 (no relevance) to 6 (highest relevance) for the items listed below.

B. Statement: "I generally follow the trend." Six response categories from 1 (complete disagreement) to 6 (complete agreement).

Spearman rank correlation coefficients with German investment share ( $p$-value)
A. Fundamental facts about the company / market
$-0.062$
$(0.452) \quad[n=148]$
Chart analysis / technical indicators
$0.142^{*}$
$(0.085)$
$[n=148]$
Discussions / exchange of views with colleagues
0.062
$(0.458)$
0.068
(0.411)
0.107
(0.196) $\quad[n=148]$
Statements of opinion leaders within the industry
(e.g. Warren Buffett)
Statements of economic opinion leaders
(e.g. Alan Greenspan, Wim Duisenberg)$$
0.295^{\star * *}(0.000) \quad[n=148]
$$
B. Following the trend
$0.246^{* * *}(0.003) \quad[n=146]$

Number of respondents in brackets. Stars refer to level of significance: ${ }^{*} 10 \%,{ }^{* \star} 5 \%,{ }^{* *} 1 \%$. 
TABLE 5. Findings on the relation of home bias with behavioral characteristics for equity managers

\footnotetext{
A. "Please estimate the development of the EuroStoxx 50 and the Dow Jones within the next month. Please forecast the performance of the respective index with a probability of $90 \%$."

B. "I prefer to take profits instead of cutting losses, when I am confronted with unexpected liquidity demands." Six response categories from 1 (complete disagreement) to 6 (complete agreement).

C. "Apart from any fund's restriction - Imagine your portfolio's performance differs from its benchmark near the end of the period."

Alternative statements: "If my portfolio has underperformed its benchmark so far, I would:

....increase the relative risk level to reach the benchmark, ... decrease the relative risk level to avoid further deficits, ...not change my strategy."
}

Spearman rank correlation coefficients with German investment share ( $p$-value)

A. Width of expected $90 \%$ probability

- for the EuroStoxx 50

$-0.164^{*} \quad(0.059) \quad[n=134]$

- for the Dow Jones

$-0.253^{* * *}(0.003) \quad[n=135]$

B. Take profits in case of liquidity demand

$0.235^{\star * *}(0.004) \quad[\mathrm{n}=145]$

C. Increase relative risk vs. no change

0.123

$(0.189) \quad[n=115]$

Decrease relative risk vs. no change

$0.166^{*}$

(0.054) $[n=135]$

Number of respondents in brackets. Stars refer to level of significance: ${ }^{*} 10 \%,{ }^{* *} 5 \%$, ${ }^{* *} 1 \%$.

TABLE 6. Stepwise regressions explaining home bias of equity managers

\begin{tabular}{|c|c|c|c|}
\hline \multirow[t]{2}{*}{ Variables } & \multicolumn{3}{|c|}{ Coefficients } \\
\hline & Model 1 & Model 2 & Model 3 \\
\hline Domestic managers better informed & $1.301^{* *}$ & $1.035^{*}$ & -- \\
\hline Yield GER - USA & $1.601^{* * *}$ & $1.541^{* * *}$ & $1.556^{* \star *}$ \\
\hline $\begin{array}{l}\text { Responsibility for asset under management } \\
\text { Source of information: }\end{array}$ & $-0.913^{\star *}$ & $-0.796^{\star *}$ & $-0.752^{*}$ \\
\hline - Opinion leaders within the industry & $-1.415^{\star *}$ & - & --- \\
\hline - Economic opinion leaders & $1.803^{* * *}$ & $1.393^{* *}$ & $1.671^{* * *}$ \\
\hline Spread of Dow Jones forecast & $-0.217^{* * *}$ & $-0.203^{\star * *}$ & $-0.164^{* *}$ \\
\hline Constant & $12.472^{* * *}$ & $10.609^{* * *}$ & $12.971^{* * *}$ \\
\hline Adjusted R-square & 0.260 & 0.241 & 0.224 \\
\hline F-statistic & $7.927^{* * *}$ & $8.479^{* * *}$ & $9.670^{* * *}$ \\
\hline
\end{tabular}

This table is based on 119 responses as it considers a German investment share between $\geq 2 \%$ and $\leq 50 \%$. Stars refer to level of significance: ${ }^{*} 10 \%,{ }^{* *} 5 \%,{ }^{* * *} 1 \%$. 
ANNEX 1. Additional findings on the hypothesis of information advantage

\begin{tabular}{lccc}
\hline $\begin{array}{l}\text { Re- } \\
\text { quest: }\end{array}$ & $\begin{array}{r}\text { "Please estimate the development of the EuroStoxx } 50 \text { and the Dow Jones within the next } \\
\text { month. Please forecast the performance of the respective index with a probability of } 90 \% . "\end{array}$ \\
& $\begin{array}{r}\text { Spearman rank correlation coefficients with German } \\
\text { investment share (p-value in parentheses) }\end{array}$ \\
Correct forecast & All managers & Equity managers & Bond managers \\
- EuroStoxx 50 & $-0.021(0.772)$ & $-0.052(0.551)$ & $0.138(0.420)$ \\
- Dow Jones & $-0.048(0.507)$ & $-0.133(0.126)$ & $0.297^{*}(0.083)$ \\
\hline
\end{tabular}

Stars refer to level of significance: ${ }^{*} 10 \%,{ }^{* *} 5 \%,{ }^{* *} 1 \%$.

ANNEX 2. Principal component analysis explaining home bias of equity managers by stepwise excluding components and variables

\begin{tabular}{|c|c|c|c|c|c|c|}
\hline \multirow[t]{3}{*}{ Variables } & \multicolumn{6}{|c|}{ Eigenvalues of variables in components } \\
\hline & \multicolumn{3}{|c|}{ Model 1} & \multicolumn{2}{|c|}{ Model 2} & \multirow{2}{*}{$\begin{array}{c}\text { Model } 3 \\
\text { C1 }\end{array}$} \\
\hline & C1 & $\mathrm{C} 2$ & C3 & C1 & $\mathrm{C} 2$ & \\
\hline Yield GER - EU & 0.688 & -0.620 & 0.060 & 0.835 & -0.405 & 0.923 \\
\hline Yield GER - USA & 0.729 & -0.599 & -0.011 & 0.885 & -0.320 & 0.923 \\
\hline \multicolumn{7}{|l|}{ Source of information: } \\
\hline - Other market players & 0.677 & 0.479 & 0.245 & 0.521 & 0.720 & --- \\
\hline $\begin{array}{l}\text { - Opinion leaders within } \\
\text { the industry }\end{array}$ & 0.483 & 0.661 & 0.269 & 0.294 & 0.839 & --- \\
\hline Educational level & 0.051 & 0.230 & 0.906 & --- & --- & --- \\
\hline Disposition effect & 0.617 & 0.336 & 0.350 & --- & --- & --- \\
\hline
\end{tabular}

This table is based on 119 responses as it considers a German investment share between $\geq 2 \%$ and $\leq 50 \%$.

AnNeX 3. Principal component analysis explaining home bias of equity managers by limiting the number of components

\begin{tabular}{lccc}
\hline Variables & \multicolumn{3}{c}{ Eigenvalues of variables in } \\
& Component 1 & Component 2 & Component 3 \\
Volume of assets under management & 0.548 & --- & --- \\
Disposition effect & 0.651 & --- & --- \\
Spread of EuroStoxx 50 forecast & 0.618 & --- & --- \\
Spread of Dow Jones forecast & 0.671 & --- & --- \\
Domestic managers better informed & --- & 0.679 & --- \\
Source of information: & --- & 0.551 & -- \\
$\quad-$ Discussions with colleagues & --- & 0.546 & 0.803 \\
$\quad-$ Opinion leaders of the industry & --- & 0.553 & 0.831 \\
$\quad-$ Economic opinion leaders & --- & --- & 0.538 \\
Yield GER - EU & --- & --- & $9.593 \%$ \\
Yield GER - USA & $14.999 \%$ & $11.923 \%$ & $36.515 \%$ \\
Yield GER - Asia & $14.999 \%$ & $26.922 \%$ & \\
Explained variance & & & \\
Cumulated explained variance & & & \\
\hline
\end{tabular}

This table is based on 119 responses as it considers a German investment share between $\geq 2 \%$ and $\leq 50 \%$. 